\title{
Habitat Suitability of Release Site for Javan Gibbon (Hylobates moloch) in Mount Malabar Protected Forests, West Java
}

\author{
Anton Ario $^{1,2^{*}}$, Agus Priyono Kartono ${ }^{3}$, Lilik Budi Prasetyo ${ }^{3}$, Jatna Supriatna ${ }^{2,4}$ \\ 'Tropical Biodiversity Conservation Study Program, Bogor Agricultural University, Jl. Raya Dramaga, Kampus IPB Dramaga, \\ Bogor 16680, Indonesia \\ ${ }^{2 *}$ Conservation International Indonesia, Jl. Pejaten Barat No.16A, Kemang, Jakarta 12550, Indonesia \\ ${ }^{3}$ Department of Forest Resource Conservation and Ecotourism, Faculty of Forestry, Bogor Agricultural University, \\ Ulin Road, Campus IPB Dramaga, Bogor, Indonesia 16680 \\ ${ }^{4}$ Department of Biology, University of Indonesia, Margonda Raya, Depok, West Java, Indonesia 16424
}

Received June 26, 2018/Accepted August 24, 2018

\begin{abstract}
The javan gibbon reintroduction program requires assessment of suitable habitat within release sites to assure the survival of released gibbons. We studied habitat suitability for javan gibbon beginning in April 2017, extending to June 2017 in the Mount Malabar Protected Forest (MMPF), West Java. The objectives of this study were to analyze the habitat suitability of the release site for javan gibbon in MMPF. Analysis of Geographical Information System (GIS) and Principal Component Analysis (PCA) approach were used to obtain habitat suitability values. Habitat suitability variables measured are elevation, Normalized Differential Vegetation Index (NDVI), Bareness Soil Index (BSI), distance from the road, farming, settlement, and open field. We found suitability valued areas consisting of high suitability covered 2,009.23 ha (22.31\%), moderate suitability covered 2,497.46 ha (27.73\%), and low suitability covered 4.499, 65 ha (49.96\%), from a total area $\pm 8.894,47$ ha in MMPF.
\end{abstract}

Keywords: habitat, javan gibbon, release, suitability

*Correspondence author, email: aario@conservation.org; phone/fax: +62-251-8224963

\section{Introduction}

Javan gibbon (Hylobates moloch) poaching for the illegal trade is a severe threat to their survival in the wild. Generally, gibbons are captured while still young, often before weaning. The mothers are usually killed in order to capture a live infant or juvenile (Supriatna 2006, Nijman 2009). Before releasing gibbons in the wild, effective rehabilitation is essential to optimize behavioral ability and to optimize behavior health that will support successful adaptation to the wild. Rehabilitation and reintroduction programs have been widely used as an element of conservation strategies for endangered species (Kleiman 1989). Reintroduction programs provide an opportunity for animals that have lived in captivity to have another chance of living in the wild and may be one way of re-establishing populations that have become locally extinct (Komdeur \& Deerenberg 1997).

The javan gibbon reintroduction program does not only focus on preparing behavior readiness and health of the gibbons. Determining a suitable release site is also essential to be considered in order to ensure the animals' survival in natural habitat. Habitat assessments are essential to determine if sufficient resources are available to support translocated gibbons. Every effort must be made to find a release habitat that resembles the natural habitat as closely as possible. Even if a site has an existing population or one that has only recently become locally extinct, a comprehensive assessment is required to ensure that there have been no significant changes in habitat quality. Long-term habitat assessment, both before and after release, can help increase the probable success of a translocation program (Cheyne 2006, Cheyne et al. 2012).

Selection of an appropriate site is a key when planning for translocations (IUCN-SSC 2013). In brief, a release site should: (a) meet all biotic and abiotic requirements of the species to be translocated, (b) be protected and have threats controlled or managed, (c) be adequate for all seasonal habitat needs, and (d) be large enough or have suitable connectivity to support a viable population (or metapopulation management strategies are in place) (Campbell et al. 2015).

An assessment of the habitat quality and its ability to sustain any translocated gibbons should be conducted. Care must also be taken to ensure that the reasons for the local declines in that area have ceased or can be addressed. If hunting and deforestation were the primary causes of the species becoming extinct in an area, then evidence must be presented to show that the problem has been eliminated or drastically reduced or projects must address these issues before translocating gibbons to the site (Campbell et al. 2015).

After a release site is determined, the next step to be considered is the exact area where the gibbon will be released. 
It is essential to choose a secure release area, away from other gibbons territories, maximizing the gibbons' opportunity to find food sources, shelter and establish their territory (Campbell et al. 2015).

Information about spatial or non-spatial data is required to map the potential relationship between habitat variable that influences javan gibbon. Proper planning can only be made possible with accurate information especially physical and biological environment aspects such as the availability of topography map, vegetation, and animal distribution. Spatial analysis can also provide information about the habitat's condition at a given time, thus occurring changes can be understood based on ecological and social factors which can be used as points of consideration in determining management policy (Berliana 2009).

Spatial analysis can provide accurate, relevant information concerning javan gibbon habitat. Spatial analysis can be applied to assess the javan gibbon's association with specific habitat components, areas that might be used as javan gibbon habitat, or javan gibbon population estimation. It can also provide information about certain habitat conditions at certain times, and it can be used to evaluate habitat changes following ecological and social factors (Dewi et al. 2007).

Deforestation in Java Island continues to occur in line with decentralization of forest management policy (Supriatna 2006). In contrast to West Java, the forest habitat in Central Java does not have any protected areas which form a network system and has received little attention among conservationists and researchers. Consequently, forest habitat in this region is more threatened by encroachment (Setiawan etal.2012).

Mount Malabar Protected Forest (MMPF) is one of javan gibbon's habitat managed by Perhutani. This area is water catchment area of Citarum watershed in West Java. This research is an initial study on forest quality in MMPF. The research is expected to provide considerations input to policymakers in managing habitat and javan gibbon in MMPF. By protecting forest means conserving the javan gibbons may survive only in the intact forest.

Habitat suitability analysis for habitat javan gibbons release site is needed to ensure the survival of the animals. In general, habitat suitability studies are conducted in an existing javan gibbon habitat. This study will be critical in providing considerations for determining javan gibbons release site.

The objective of this study is to analyze the habitat suitability of the release site for javan gibbon in MMPF through Geographical Information System (GIS) analysis.

\section{Methods}

Time and location study This research was conducted for 3 months from April to June 2017 in Mount Gede Pangrango National Park (MGPNP) and Mount Malabar Protection Forest (MMPF), West Java. The MGPNP was located between $\mathrm{S}^{\circ} 41^{\prime} 65^{\circ} 1^{\prime}$ and $\mathrm{E} 106^{\circ} 51^{\prime} 107^{\circ} 02^{\prime}$ at altitudes of $7003.019 \mathrm{~m}$ asl. The MGPNP is covering 24.270,80 ha of forest area which laid in the districts of Cianjur, Sukabumi, and Bogor. The MMPF was located between S07 $07^{\prime} 20.52^{\prime \prime}$ and E107'36'28.48' at altitudes of 1,0002,300 $\mathrm{m}$ asl. It has an area of about 8.894,47 ha located in Bandung Regency (Figure 1).

Data Collection and Analysis Data used in this study consist of primary and secondary data. Primary data are the result of a field survey in the form of javan gibbon sighting location point and its habitat condition in MGPNP and habitat condition data of MMPF as a reintroduction site. Secondary data are forest function map, digital topographic maps, and satellite images.

The data on javan gibbon distribution in MGPNP were collected by using triangle count and direct count along the available track in the study area. Field survey equipment which consists of Bushnell 1250mm, Global Position System

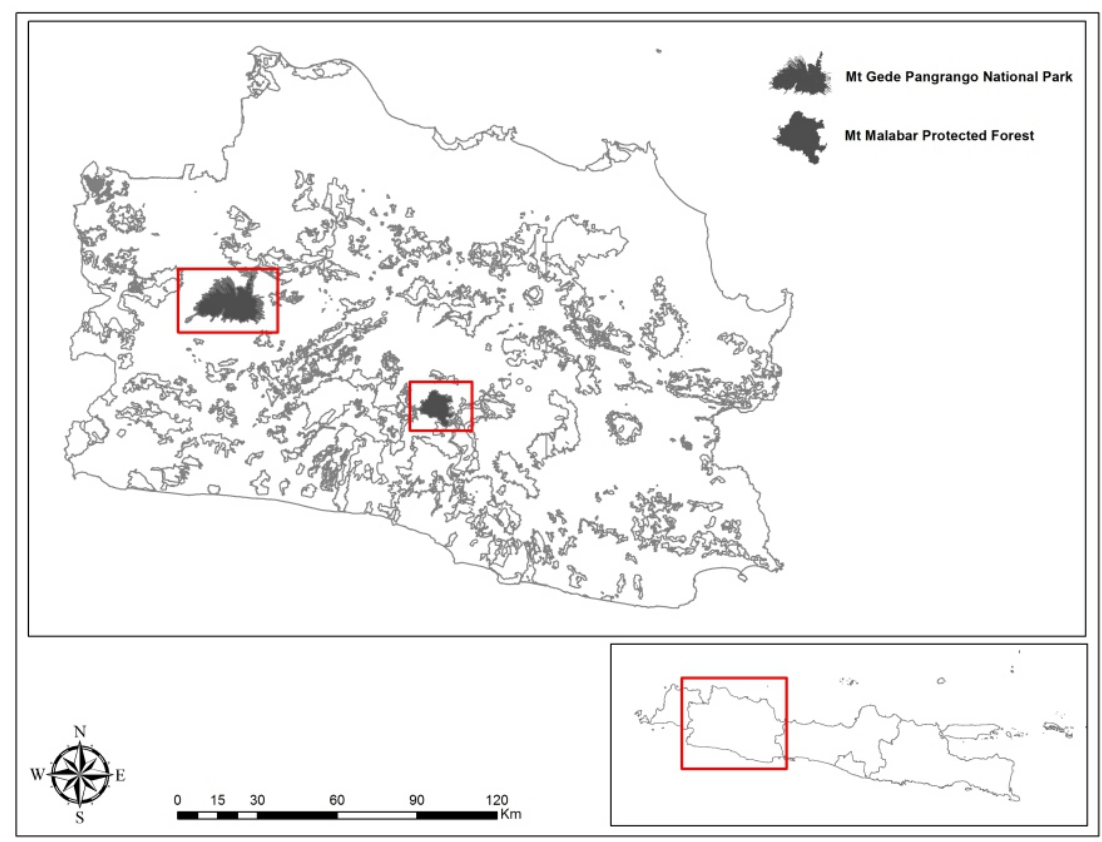

Figure 1 Map of study sites. 
Garmin Montana 650, compass, and Canon SX510 HS 30 optical zoom digital camera. Used to capture javan gibbon site of sighting and its habitat conditions.

Habitat suitability analysis of javan gibbon was based on some data sources including several maps consist of: forest function map of MMPF (source: Perhutani), digital topographic maps of MMPF (scale 1:25000, source: Geospatial Information Agency year 2014), images from Sentinel-2A Satellite (source: https://scihub.copernicus.eu, date obtained July 4th, 2017 and July 24th, 2017), images from Landsat 8 Satellite (source: https://www.earthexplorer. usgs.gov, date obtained August 4th, 2017), and Digital Surface Model (DSM) (source: http://www.eorc.jaxa.jp/). Tools for data analysis which consist of a computer, calculator, stationary, ArcGIS ver.10 and SPSS ver.14 software.

The data from the field survey in MGPNP was used by this system to determine javan gibbon habitat suitability in MMPF. Geolocation data on javan gibbon sighting in MGPNP is used as base data in sampling each variable considered to be relevant in illustrating javan gibbon's habitat suitability, which consists of: (a) physical factor is elevation, (b) biotic factor are Normalized Differential Vegetation Index (NDVI) and Bareness Soil Index (BSI), (c) human intervention factor is distance from road, farms, settlement, and open field.

Habitat suitability mapping of javan gibbon was created by classifying the matrix of suitability, including the selection of habitat variables. A Geographical Information System (GIS) technique is used for mapping the habitat suitability of wildlife species (Rubert 2007). Data analysis utilizing GIS is used in various application to assess habitat fragmentation and create species distribution model (Apan 1996, Jorge \& Garcia 1997, He et al. 1998). These habitat suitability models are based on a functional relationship between wild animals and habitat variables (U.S. Fish and Wildlife Service 1980; 1981). A synthesis on wildlife-habitat relationship knowledge, multivariate habitat analysis, with wildlife mapping techniques (which primarily done with specific GIS software) is the very promising method to produce practical wildlife information for management practices (Miller 1994).

The elevation is a habitat parameter that affects the distribution of wildlife. The javan gibbon can be found at an altitude of up to $1,500 \mathrm{~m}$ asl, but in some cases, it can still be found at an altitude of 2,000 $\mathrm{m}$ asl. Location altitude is obtained through Digital Elevation Model (DEM) data.

NDVI and BSI used to identify the level of land cover in an area. NDVI and BSI are different indices, the more vegetation's density the NDVI values are higher, but the opposite is the BSI value. To get NDVI and BSI values is done by processing sentinel image (for NDVI) and Landsat (for BSI) imagery with each formula as follows as Equation [1] and Equation [2].

$$
B S I=\frac{(S W I R-R E D)-(N I R-B L U E)}{(S W I R+R E D)+(N I R+B L U E)}
$$

$N D V I=\frac{N I R-R E D}{N I R+R E D}$

note: NIR $=$ reflectance canal near infrared, RED = reflectance canal red, SWIR $=$ reflectance canal SWIR 1,
BLUE $=$ ceflectance canal blue

Each parameter of human activities impact is a parameter that is considered to represent the factor of human interference. Javan gibbons must choose to avoid direct encounters with humans. Distance from the road is obtained from Indonesian Rupa Bumi (RBI) data by performing euclidean distance process to get the distance perpendicular to the road. The Euclidean distance process is also applied to obtain distance data from the settlement, distance from farmland and distance from open land extracted from an analysis of land cover in 2017 around MMPF.

Variable values obtained in javan gibbon's points in MGPNP were processed by principal component analysis (PCA) approach. PCA was used to statistically process the weight of each environmental variable for javan gibbon habitat. It was determined by overlaying the current locations of javan gibbon distribution. Each location of javan gibbon distribution comprised values (Suheri et al. 2014).

The number of habitat component used as a variable is hard relatively to be understood and illustrated as a unity of habitat components which each other influences. The difficulty in illustrating the association between variables can be simplified by PCA which is a variable simplifying method that represents information existing in previous variables. PCA result then applied and re-mapped on MMPF area with PCA general as Equation [3]:

$$
P C A=\uparrow_{i=1}^{\uparrow}\left(L F_{i} \times P C_{i}\right)
$$

note: $\mathrm{LF}_{\mathrm{i}}=$ loading factor component in $i$ sequence, $\mathrm{PC}_{\mathrm{i}}=i$ sequence $\mathrm{PC}$

The result calculated by PCA is used to make habitat suitability classes where its acquired value used geometric interval by separating the area into three classes of habitat suitability, which are unsuitable, moderate suitability, and high suitability classes. Habitat suitability map result obtained by PCA was then revised by using land coverage map, forest condition, and elevation, to obtain new habitat suitability map. The revision from PCA result habitat suitability map was done to obtain a better result in dividing habitat suitability classes. The revision is created by overlaying previously known habitat that is known not to be javan gibbon habitat which then added as the unsuitable class. This classification based on similar research has conducted by Dewi et al. (2007), Ikbal et al. (2008), Berliana (2009), and Suheri et al. (2014).

\section{Results and Discussion}

Javan gibbon spatial distribution in MGPNP Twentyeight javan gibbon sighting point managed to be obtained in 8 MGPNP resorts, which are Cibodas, Nagrak, Cimungkad, Situgunung, Selabintana, Tapos, Cimande, and Bodogol. Out of the 28 points, there was one point that cannot be used as reference data, which is the Pasir Masigit point in Situgunung Resort. This is because the Landsat image of the location is covered by cloud. The presence of cloud or its shadow are disturbances that can affect image spectral value. Iskandar et al. (2009) stated the javan gibbon found in 5 resorts in MGPNP, which are Cisarua, Cimungkat, Bodogol, Situ Gunung, and Cibodas, but absent in Selabintana and 


\section{Gunung Putri.}

Javan gibbon distribution based on physical factor (elevation) was located in $700900 \mathrm{~m}$ asl and lowest at $>1,700$ $\mathrm{m}$ asl. Based on biotic factor, the highest NDVI index value is 0.70 .8 and BSI is $-0.4--0.3$. Based on human intervention factor, the highest values for each are distance from road 22.5 $\mathrm{km}$, distance from farms $11.5 \mathrm{~km}$, distance from settlements $2.53 \mathrm{~km}$, and distance from open field $>3 \mathrm{~km}$ (Figure 2).

According to Suheri et al. (2014), identification of habitat suitability is a crucial aspect of conservation management. The study in MGPNP attempts to develop habitat suitability and corridor setup for javan gibbon in MGPNP, based on some identified environmental variables in the fieldwork area. In a total area of 22,851 ha, it showed that $17.15 \%(3,918 \mathrm{ha}), 38.61 \%(8,823 \mathrm{ha})$ and $44.24 \%$ $(10,110 \mathrm{ha})$ are classified to have high, moderate and low suitability for javan gibbon habitat, respectively.

MMPF habitat suitability factors Some of the assessed
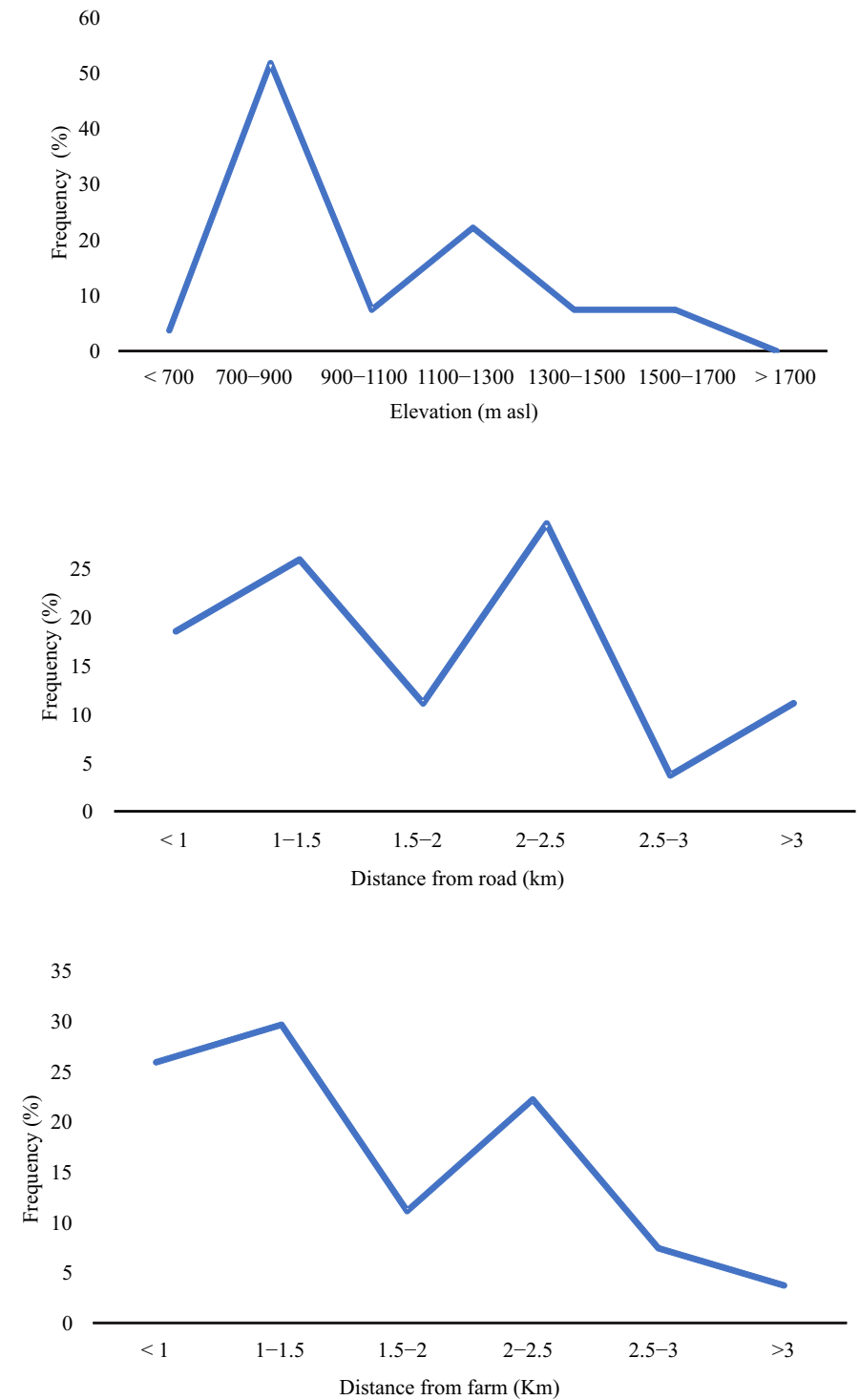

variables can illustrate the suitability of Javan gibbon habitat in MMPF which includes physical factors (elevation), biotic factors (NDVI and BSI), as well as human disturbance factors consisting of the distance from roads, agriculture, settlements and open land (Figure 3).

Other previous research on javan gibbon habitat suitability used the distance from the river and sloping land variable. However, in this research, those variables are not included for they are not affecting javan gibbon distribution.

As an arboreal primate, javan gibbon rarely goes down to forest ground or river edges. Javan gibbon water intake is fulfilled from fruits they ingest, dew on leaves, and rainwater accumulating on tree bark (Napier \& Napier 1985).

Land sloping level is also believed not to affect javan gibbon distribution because in general conservation and nonconservation area which are the habitat of javan gibbon in West Java are mountain forest with sloping level varied from level to steep. javan gibbon is arboreal animals, and thus land slope factor is not a hindrance for their accessibility (Dewi et
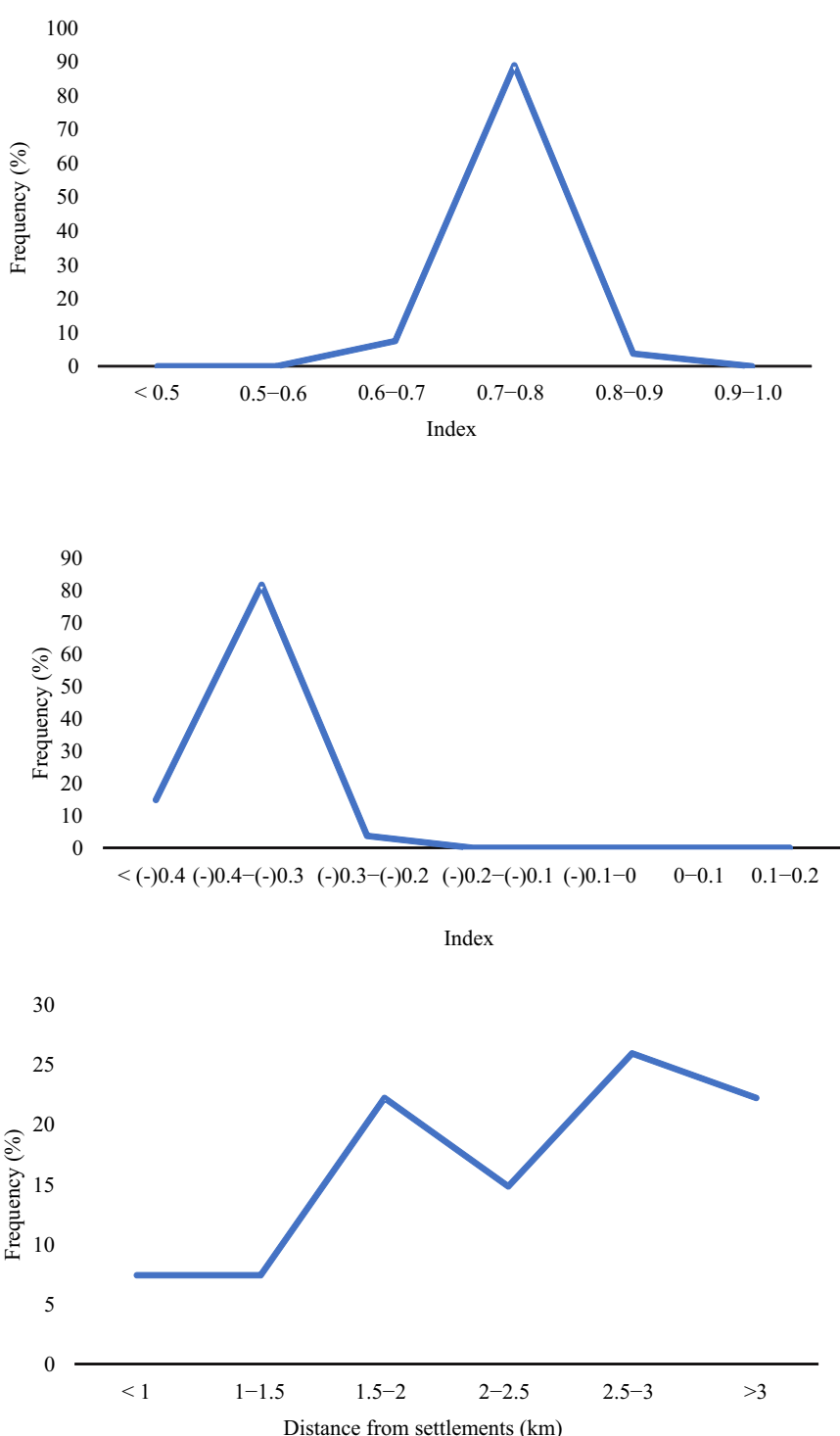

Figure 2 Diagram of javan gibbon distribution in MGPNP based on: (a) elevation, (b) NDVI, (c) BSI, (d) distance from road, (e) distance from farm, (f) distance from settlements, $(\mathrm{g})$ distance from open land. 


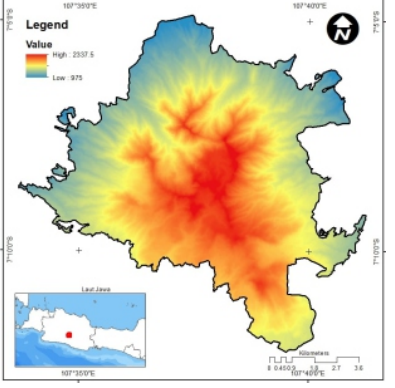

(a)

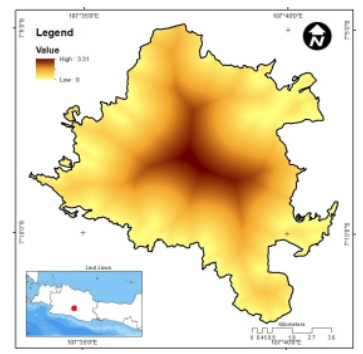

(d)

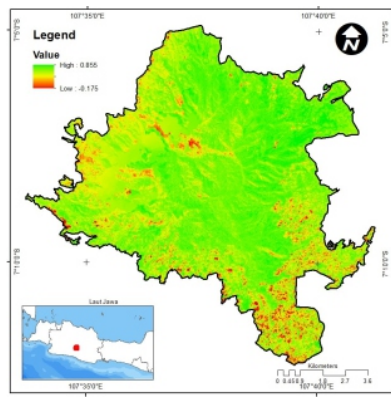

(b)

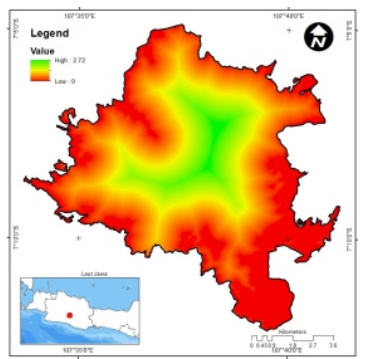

(e)

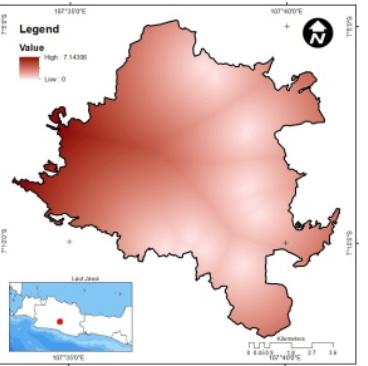

$(\mathrm{g})$

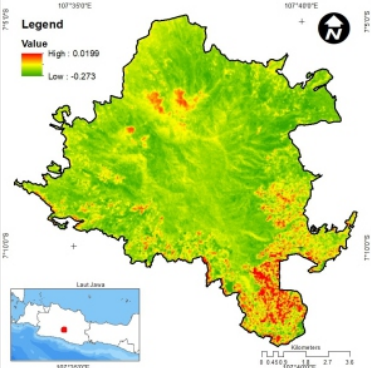

(c)

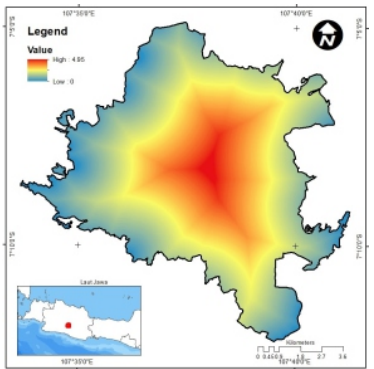

(f)

Figure 3 Map of habitat suitability variables in MMPF based on: (a) elevation, (b) NDVI, (c) BSI, (d) distance from road, (e) distance from farm, (f) distance from settlements, (g) distance from open field.

al. 2007). Javan gibbon groups in Mount Halimun-Salak National Park (MHSNP) are found more in steep topography, presumably to avoid predators (Rinaldi 2003).

Habitat suitability shows the affordability of a unit of land to support species survivals. The affordability is determined by the spatial properties and not just resources inside it. In the geographic scale, habitat resources could be represented by smaller scale features (spatial features) as auxiliary variables (Guisan \& Zimmermann 2000).

Physical factor Physical factors counted in this research are elevation, where found in javan gibbon distribution data in MGPNP were 7001,700 $\mathrm{m}$ asl, and in MMPF between 975 to $2,337.5 \mathrm{~m}$ asl. Elevation factor is essential to consider as it is linked to feeding availability, abundance, and variations of fruits as their main forage. It is also associated with javan gibbon's movements which are mostly done by brachiation and depend on forest tree branching condition.

Javan gibbon lives in tropical rainforest from coastal areas, lowland, to mountain up to $1,600 \mathrm{~m}$ asl. The highest density of javan gibbon was found in lowland area up to
$1,300 \mathrm{~m}$ asl (Wedana et al. 2009). Javan gibbon is rarely found in more than $1,500 \mathrm{~m}$ asl for their source of feed is scarce in that altitude. According to Nijman (2004), javan gibbon can be found in areas up to $1,600 \mathrm{~m}$ asl, however in some cases they can be found in more than $2,000 \mathrm{~m}$ asl. Low temperature and high humidity can also promote the growth of moss, which may cover tree branch, hindering javan gibbon's brachiation movement (Kappeler 1984, Rowe 1996, Supriatna \& Wahyono 2000).

Javan gibbons primary locomotion is brachiation. Other types of locomotion include climbing, leaping, and bipedalism. Brachiation is moving horizontally using both forelimbs to keep body weight and swing among tree branches (MatsumotoOda \& Oda 1998). As a frugivore, javan gibbon consumed more fruits $(61 \%)$, compared to bud and young leaves $(38 \%)$, and flowers (1\%), coming from 125 types of plants in total. Javan gibbons also consumed several types of insects, such as termites (Kappeler 1981, Supriatna \& Wahyono 2000).

Biotic factors Javan gibbon spotting graphic against NDVI value showed that javan gibbon are only found in MGPNP area with high NDVI index, which is 0.70 .8 . This density 
value was also found in MMPF with the highest index being 0.85 . The value showed that javan gibbon habitat in MGPNP and MMPF tend to be located in forests with high density.

Inversely, BSI showed that javan gibbon in MGPNP tends to choose habitat with low BSI, with the value of -0.4 0.3 . This low value of BSI was also found in MMPF with 0.27 . High vegetation density with low BSI in MGPNP and MMPF were suitable habitat for javan gibbon.

The most suitable javan gibbon habitat is in the locations that are covered by both primary and secondary forests (Leighton 1987). Javan gibbons are frugivorous arboreal primates whose lives are influenced by habitat condition such as vegetation stand, tree density, food types variations, and canopy closure (Kappeler 1984). The gibbon requires a forest with connected canopy, trees with a height more than $25 \mathrm{~m}$, and a high diversity of fruit-producing trees (Cheyne $e t$ al. 2013). The javan gibbons spend most of their daily activities in the highest canopy strata, on $2025 \mathrm{~m}$ (Nijman 2001).

Processes impacting habitat quality are of particular concern for the long-term viability of resident gibbon populations. Selective logging, whether commercial or illegal, can alter the carrying capacity of an area, displacing gibbons causing increased intergroup contacts and conflicts, increased stress and mortality (especially in infants) and other adverse effects (Rainer et al. 2014).

Human disturbance factors Human disturbance factors can be represented as the distance from road, farm, settlement, and open field. The highest habitat suitability value from human disturbance aspect from each variable are as follow: the distance from road in MGPNP between $2.53 \mathrm{~km}$, and in MMPF within $3.31 \mathrm{~km}$; based on distance from farming area in MGPNP between $11.5 \mathrm{~km}$, and in MMPF within $2.72 \mathrm{~km}$; based on distance from settlement in MGPNP between 2.53 $\mathrm{km}$, and MMPF within $4.95 \mathrm{~km}$; and based on distance from open field in MGPNP being $>3 \mathrm{~km}$, and in MMPF within $7.14 \mathrm{~km}$.

The closer the distance with the center of human activity and their transportation route, the more intensive the disturbance from human to the environment. This disturbance arises from the ease of access into the area. The closer to places of human activity, the intensity of javan gibbon spotting is decreasing.

MMPF area has relatively easy access to the nearest villages, and thus the majority of people in these villages do their activities around the areas. The existence of "Community Based Forest Management" program (PHBM) by Perhutani opens the possibility for people to do their activities in MMPF areas, such as coffee plantation or even vegetable (although it is not allowed by the management). Most often disturbance is bird hunting and land opening for farming, which at times is not only done in areas utilized as production forest in the past but also spread into protection forest. Although access is mostly limited to the footpath, villagers can still use a motorcycle to reach forest area.

The javan gibbon is very sensitive to habitat changes (Pranasai et al. 2010). Human pressure is believed to be an obstacle of javan gibbon movement and dispersal. Some researchers describe that habitat destruction was a significant cause of the decline in the populations of primates, including the species of gibbons (Ganzhorn 2003, Setchell \& Curtis 2003).

Habitat suitability level based on distance from the road has the highest value, which means the further it is from the road the more suitable MMPF is as javan gibbon release site. The closer it is to the road, the lower javan gibbon habitat suitability in MHSNP (Dewi et al. 2007). Javan gibbon habitat suitability will lower the closer it is with human disturbance factor such as settlements, road, and so on (Ikbal et al. 2008)

Primates more often display negative reaction by making warning vocalizations, running, or moving to higher elevation in trees to avoid or not giving virtually any changes in reaction by human presence (Tobing 2002). Javan gibbon response to approaching human is avoidance. Other responses that may be found are maintaining silence and hiding. Vocalization response usually occurs if the animal has detected human presence at a very close distance (Nijman 2004)

Habitat suitability for the reintroduction of javan gibbons Historical data on the rearing origin in the rehabilitation process of javan gibbons at JGC was used as a consideration in determining the release site candidates. The data was mostly the origin of java gibbons from Bandung, Cianjur and Sukabumi regencies. Therefore, the identification of forest areas suspected to be the habitat of javan gibbons is made in the area around the three regencies. One of the considerations is to survey the existence for wild java gibbons in forest areas in the three districts. Based on the results of the survey, it was known only in MMPF that there was no wild population of javan gibbon, although its presence was known before 1997. Therefore, the initial determination of the release site was MMPF. One of the criteria has recommended for primate release sites is there are no wild populations (Beck et al. 2007), to avoid animals released carrying disease (Cheyne et al. 2005). Also, ecological surveys to obtain the flora and fauna data available in the area, as well as the socio-economic survey of the community were conducted.

According to Campbell et al. (2015) before a translocation can be conducted at a proposed release site, a population assessment should be conducted to determine whether an existing gibbon population persists there. Sites which have a resident gibbon population require different considerations from those who do not; the former represents population reinforcement while the latter represents a reintroduction.

A release site should provide a long-term secure habitat with limited potential for reduction in size, encroachment, infrastructure development or significant change in surrounding area due to these activities (Campbell et al. 2015).

Analyzed by PCA generated KMO (Kaisar-MeyerOlkin) value and Bartlett test value 0.583 with $1.67 \mathrm{E}-16$ significance. KMO and Bartlett test values are more than 0.5 and significance is $<0.001$, and thus the result can be accepted and progressed to the next process (Table 1). PCA analysis to javan gibbon distribution value in MGPNP resulted in total 3 new variables with Eigen value $>1$ and represent $82.5 \%$ of previous variables (Table 2). New 
Table $1 \mathrm{KMO}$ and Bartlett's test

\begin{tabular}{llc}
\hline $\begin{array}{l}\text { Kaiser-Meyer-Olkin Measure } \\
\text { of Sampling Adequacy. }\end{array}$ & 0.583 \\
\hline Bartlett's Test of Sphericity & Approx. Chi-Square & 123.435 \\
& df & 21 \\
& Sig. & 0.000 \\
\hline
\end{tabular}

Table 3 Matrix component

\begin{tabular}{lccc}
\hline & \multicolumn{3}{c}{ Component } \\
\cline { 2 - 4 } & 1 & 2 & 3 \\
\hline DEM & -0.305 & 0.800 & 0.024 \\
Road & 0.946 & 0.279 & -0.023 \\
Farm & 0.945 & 0.202 & -0.109 \\
Build & 0.850 & 0.295 & 0.306 \\
NDVI & 0.162 & -0.339 & 0.855 \\
BSI & -0.190 & 0.707 & -0.064 \\
Open land & -0.546 & 0.500 & 0.509 \\
\hline
\end{tabular}

variables component formed can be seen in a component matrix (Table 3). The formula given as the result of PCA is as shown in Equation [1]

$\mathrm{PCA}=2.964 \mathrm{PC} 1+1.71 \mathrm{PC} 2+1.101 \mathrm{PC} 3$

Commonalities can explain how much the new variable formed from PCA can explain the previous variables. Table 4 shows that the new variable formed is highest when influenced by distance from road variable.

PCA result is then mapped by using the same variable against MMPF. The result given by PCA is compared by actual condition, with areas known to be unsuitable as javan gibbon habitat. These areas can be known from land cover analysis and forest condition in MMPF. The PCA result obtained are then revised with land coverage, elevation, and forest condition. After revision is done against PCA result, classes of javan gibbon habitat suitability in MMPF is as follow: high suitability (22.31\%) for 2,009.23 ha, moderate suitability $(27.73 \%)$ for $2,497.46$ ha, and low suitability $(49.96 \%)$ for 4.499,65 ha (Table 5, Figure 4).

Based on this result, it can be concluded that MMPF can be used as javan gibbon release site on its moderate and high suitability areas. Figure 4 also shows the location of four javan gibbons groups released period 20142016 in MMPF, located in a moderate to high suitability area. This proves that a suitable habitat can meet the needs of post-release javan gibbons including feed and cover in MMPF. According to Ario et al. (2018), each group started from its different release site, and slowly expanded their movement to have
Table 2 Total variance explained

\begin{tabular}{cccc}
\hline & \multicolumn{3}{c}{ Initial eigenvalues } \\
\cline { 2 - 4 } Component & Total & \% of variance & Cumulative \% \\
\hline 1 & 2.964 & 42.346 & 42.346 \\
2 & 1.710 & 24.427 & 66.773 \\
3 & 1.101 & 15.724 & 82.498 \\
4 & 0.682 & 9.743 & 92.241 \\
5 & 0.401 & 5.727 & 97.967 \\
6 & 0.117 & 1.674 & 99.641 \\
7 & 0.025 & 0.359 & 100.000 \\
\hline
\end{tabular}

Table 4 Communalities

\begin{tabular}{lll}
\hline & Initial & Extraction \\
\hline DEM & 1.000 & 0.734 \\
Road & 1.000 & 0.974 \\
Farm & 1.000 & 0.946 \\
Build & 1.000 & 0.903 \\
NDVI & 1.000 & 0.872 \\
BSI & 1.000 & 0.540 \\
Open land & 1.000 & 0.806 \\
\hline
\end{tabular}

bigger home range. This is related to the distribution and abundance of feed around the release site. The released javan gibbon explored the area not only to find food but also to investigate sound produced by other animals or humans.

The areas with high and moderate suitable habitat were located mostly in the middle part of MMPF. In the middle of MMPF secondary forest has the general characteristic of mountainous rainforest trees species in West Java, such as Ficus pistulosa, Lithocarpus pallidus, Alstonia scholaris, Altingia excelsa, Dixocsillum aliaceum, Persea excelsa, Rhodamnia cinereal, etc. In line with the area's status, MMPF consists of natural forest vegetation (secondary forest) and plantation forest such as pine and eucalyptus which are remnants of Limited Production Forest (HPT), as a buffer zone of secondary forest.

Javan gibbon can only live in heterogeneous forest; thus pine and eucalyptus forest that is mostly homogenous cannot be used as habitat for its lack of food availability. The most important habitat component for the animal is the food source. Food availability usually changes with the season. The quantity and quality of food needed by every wildlife varied according to species, sex, age, physiological function, season, weather, and geographical location (Bailay 1984).

Forest structure and composition should be assessed in potential release sites. Canopy connectivity and density are critical, as is the height, size, and presence of specialist trees (Mather 1992, Cheyne et al. 2006). Levels of existing and potential fragmentation should also be identified. The site 


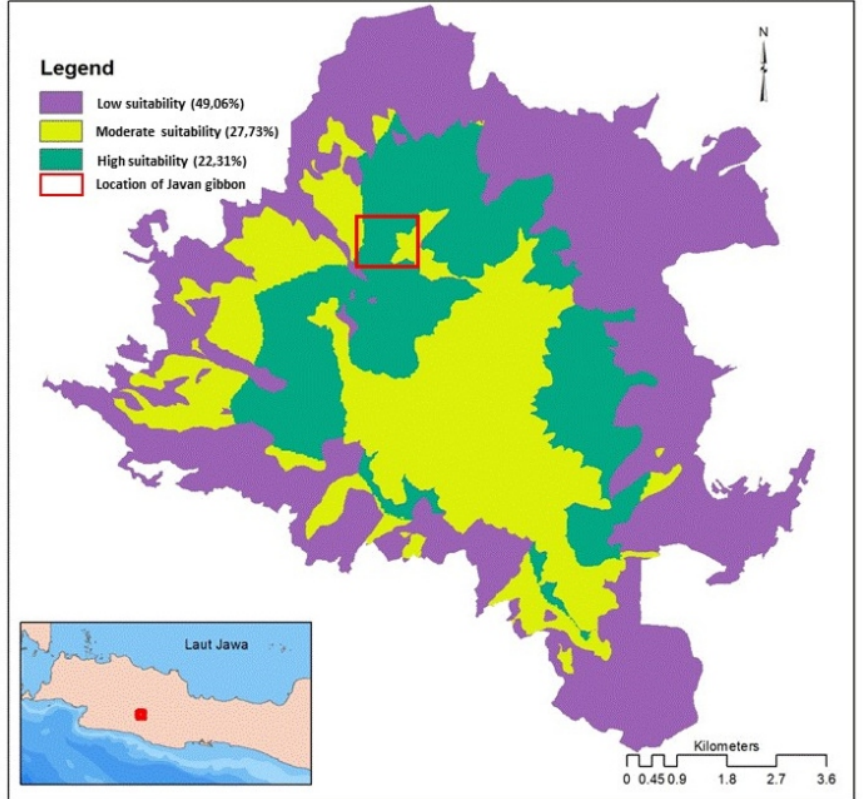

Figure 4 Map of javan gibbon habitat suitability in MMPF.

should be evaluated for suitable food types, water availability and sleeping sites (Abbott 2000, Cheyne et al. 2006; 2013). It is essential that there are enough emergent trees from which gibbons can call (to allow the call to carry) and afford gibbons protection from predators while they are sleeping (Whitten 1982, Reichard 1998, Chetry et al. 2008, Fan \& Jiang 2010, Phoonjampa et al. 2010, Cheyne et al. 2013).

In areas with significant seasonal variation in fruiting, surveys should be conducted over a period that allows a complete cyclical/annual assessment of food availability. This should be assessed in parallel with existing knowledge of the ecology of the species to be translocated. It should be ensured that the release site is within the altitudinal range of the species of gibbon taxon introduced (Campbell et al. 2015).

The implication for the management authority The results of this study are an essential finding can provide input to policymakers about the importance of wildlife management especially conservation of javan gibbons and their habitats. MMPF has become release site of javan gibbon since 2014. A lesson learned from the past important to ensure that javan gibbon released will survive and there is no more poaching, and no forest degraded in MMPF. The management authority must be improving patrol, ecosystem restoration, public awareness, education, and community empowerment. MMPF is vulnerable to damage caused by human activity such as land opening for farming. Protection forest area has a regional buffer area previously used as Limited Production Forest (HPT) which grants access into protected forest area.

Moreover, if Perhutani implements community Based Forest Management (PHBM) program with minimum supervision, encroachment into the forest will extend into the protected forest area. This implication will affect the life of wildlife living in the area, including the released javan gibbon. Thus, there is a need for more supervision by
Table 5 Javan gibbon habitat suitability result

\begin{tabular}{lcc}
\hline Level of suitability & Size (ha) & Percentage (\%) \\
\hline High & $2,009.23$ & 22.31 \\
Moderate & $2,497.56$ & 27.73 \\
Low & $4,499.65$ & 49.96 \\
\hline
\end{tabular}

management upon PHBM implementation and increasing security around the area as well as educating surrounding villagers).

\section{Conclusion}

Habitat suitability of javan gibbon release site is an important aspect to ensure javan gibbon's extended survival post-release. Food availability, vegetation density, and vulnerability risk are essential points to be considered when choosing forest area that will be used as javan gibbon release area. The habitat suitability valued areas for the MMPF javan gibbon release site consist of high suitability covered 2,009.23 ha (22.31\%), moderate suitability covered 2,497.46 ha $(27.73 \%)$, and low suitability covered $4.499,65$ ha $(49.96 \%)$ from total area $\pm 8.894,47$ ha. Based on results, MMPF can be used as javan gibbon release site on its moderate and high suitability areas. The javan gibbon groups released period 20142016, located in a moderate to high suitability areas.

\section{Acknowledgement}

We thank Conservation International Indonesia, Javan Gibbon Foundation, Mount Gede Pangrango National Park and Forestry State Enterprise of Regional Division of West Java-Banten. We would like to also thank Clare Campbell and Holly Thompson from Wildlife Asia and Silvery Gibbon Project, Arcus Foundation, Full Circle Foundation, and PT. Pertamina EP Asset 3 Subang Field, who have supported the Javan Gibbon rehabilitation and reintroduction program. We thank Ramdhoni who helps for GIS analyses, and the Javan Gibbon monitoring team in Gunung Puntang: Mulya Hermansyah, Eryan Hidayat, Uwas, Yanto, Asep Sunarya, Agus Setiawan, Jenal, Nandang, and Ade Candra.

\section{References}

Abbott I. 2000. Improving the conservation of threatened and rare mammal species through translocation to islands: A case study, Western Australia. Biological Conservation 93:95-201. https://doi.org/10.1016/S0006-3207(99) 00144-5.

Ario A, Kartono AP, Prasetyo LB, Supriatna J. 2018. Postrelease adaptation of javan gibbon (Hylobates moloch) in Mount Malabar Protected Forest, West Java, Indonesia. Biodiversitas 19(4):1482-1491. https://doi.org/10.13057/ biodiv/d190439.

Apan AA. 1996. Tropical landscape characterization and analysis for forest rehabilitation planning using satellite data and GIS. Landscape and Urban Planning 34:45-54. https://doi.org/10.1016/0169-2046(95)00201-4. 
Bailey JA. 1984. Principle of Wildlife Management. New York: John Wiley and Sons.

Beck B, Walkup K, Rodrigues M, Unwin S, Stoinski DTT. 2007. Best Practice Guidelines for the Re-introduction of Great Apes. Abu Dhabi (AE): IUCN/SSC Re-introduction Specialist Group.

Berliana K. 2009. Pemetaan kesesuaian habitat Owa Jawa (Hylobates moloch Audebert, 1798) di Cagar Alam Gunung Tilu Kabupaten Bandung dengan Aplikasi Sistem Informasi Geografis [tesis]. Bogor: Bogor Agricultural University.

Campbell CO, Cheyne SM, Rawson BM. 2015. Best Practice Guidelines for the Rehabilitation and Translocation of Gibbons. Gland: IUCN SSC Primate Specialist Group.

Cheyne SM, Hoing M, Rinear AJ, Sheeran LK. 2013. Sleeping site selection by agile gibbons: The influence of tree stability, fruit availability, and predation risk. Folia Primatologica 89:299-311.

Cheyne SM, Campbell C, Payne KL. 2012. Proposed guidelines for in situ gibbon rescue, rehabilitation and reintroduction. International Zoo Yearbook 46:1-17. https://doi.org/10.11N//j.1748-1090.2011.00149.x.

Cheyne SM, Chivers DJ, Sugardjito J. 2006. Wildlife reintroduction: Considerations of habitat quality at the release site. BioMed Central Ecology 6(1):1-8. https://doi.org/10.1186/1472-6785-6-5.

Cheyne SM. 2006. Wildlife reintroductions: Consideration of habitat quality at the release site. BMC Ecology 6:1-8.

Cheyne SM, Chivers DJ, Sugardjito J. 2005. Proposed guidelines for gibbon rehabilitation. 231. http://www.iucnsscrsg.org/pages/1/index.htm [27 January 2009].

Chetry D, Chetry R. Bhattacharjee PC. 2007. Hoolock, The Ape of India. Mariani, Assam: Gibbon Conservation Centre and Gibbon Wildlife Sanctuary.

Dewi H, Prasetyo LB, Rinaldi D. 2007. Pemetaan kesesuaian habitat owa jawa (Hylobates moloch 1798) di Taman Nasional Gunung Halimun-Salak. Media Konservasi 12(1):1-9.

Fan PF, Jiang XL. 2008. Sleeping Sites, Sleeping Trees, and Sleep-related Behaviors of Black Crested Gibbons (Nomascus concolor jingdongensis) at Mt. Wuliang, Central Yunnan, China. American Journal of Primatology 70:153-160. https://doi.org/10.1002/ajp.20470.

Ganzhorn JU. 2003. Habitat description and phenology. In: Setchell JM, Curtis DJ, editors. Field and Laboratory Methods in Primatology. Cambridge: Cambridge University Press. https://doi.org/10.1017/CBO9781139 165105.005.
Guisan A, Zimmermann NE. 2000. Predictive habitat distribution models in ecology. Ecological Modelling 135:147-186. https://doi.org/10.1016/S03043800(00)00354-9.

He HS, Mladenoff DJ, Radeloff VC, Crow TR. 1998. Integration of GIS data and classified satellite imagery for regional forest assessment. Ecological Applications 8(4): 1072-1083. https://doi.org/10.1890/10510761(1998)008[1072:IOGDAC]2.0.CO;2.

Ikbal W, Prasetyo LB, Risdiyanto I. 2008. Habitat suitability of javan gibbon in Gunung Salak, West Java. Jurnal Manajemen Hutan Tropika 14(1):1-8.

Iskandar F, Mardiastuti A, Iskandar E, Kyes RC. 2009. Populasi owa jawa (Hylobates moloch) di Taman Nasional Gunung Gede Pangrango, Jawa Barat. Jurnal Primatologi Indonesia 6(1):14-18.

IUCN-SSC. 2013. Guidelines for Reintroductions and Other Conservation Translocations. Gland: IUCN Species Survival Commission.

Jorge LAB, Garcia GJ. 1997. A study of habitat fragmentation in South East Brazil using remote sensing and geographic information system (GIS). Forest Ecology and Management 98:35-47. https://doi.org/10.1016/S03781127(97)00072-8

Kappeler M. 1981. The javan silvery gibbon (Hylobates lar moloch) [dissertation]. Basel: Universität Basel.

Kappeler M. 1984. Diet and Feeding Behaviour of the Moloch Gibbon. Edinburgh: Edinburgh University Press.

Kleiman DG. 1989. Reintroduction of captive mammals for conservation. BioScience 39:151-163. https://doi.org/10.2307/1311025.

Komdeur J, Deerenberg C. 1997. The importance of social behaviour studies for conservation. In: Clemmons JR, Buchholz R, editors. Behavioural Approaches to Conservation in the Wild. Cambrigde: Cambridge University Press.

Leighton DSR. 1987. Gibbons: Territoriality and monogamy. In: Smuts BB,Cheney D, Seyfarth L, Wrangham RM, Struhsaker TT, editors. Primate Societies. Chicago: University of Chicago Press.

Matsumoto-Oda A, Oda R. 1998. Changes in activity budget of cycling female Chimapanzes. American Journal of Primatology 46:157-166.

Mather R. 1992. Distribution and abundance of primates in Northern Kalimantan Tengah: Comparisons with other parts of Borneo, and Peninsular Malaysia. In: Ismail G, Mohamed M, Omar S, editors. Forest Biology and Conservation in Borneo. Kota Kinabalu: Sabah Foundation. 
Miller RI. 1994. Setting the scene. In: Miller RI, editor. Mapping the Diversity of Nature. London: Chapman \& Hall. https://doi.org/10.1007/978-94-011-0719-8 1.

Napier JR, Napier PH. 1985. The Natural History of The Primate. Cambridge: MIT Press

Nijman V. 2001. Forest (and) primate's conservation and ecology of the endemic primates of Java and Borneo. The Trompobos Kalimantan Series 5. Wageningen: Trompobos.

Nijman V. 2004. Conservation of the javan gibbon Hylobates moloch: Population estimates, local extinction, and conservation priorities. The Raffles Buletin of Zoology 52(1):271-280.

Nijman V. 2009. Saved from trade: Donated and confiscated gibbons in zoos and rescue centers in Indonesia. Endangered Species Research 9:151-157. https://doi.org/ $10.3354 /$ esr00218.

Phoonjampa R, Koenig A, Borries C, Gale GA, Savini, T. 2010. Selection of sleeping trees in pileated gibbons (Hylobates pileatus). American Journal of Primatology 72:617-625. https://doi.org/10.1002/ajp.20818.

Pranasai K, Priyanto, Jumilawaty E. 2010. Rehabilitation of Javan Gibbon Habitat in the Corridor Halimun-Salak Mountain. Bogor: Bogor Agricultural University.

Rainer H, White A, Lanjouw A, editors 2014. State of The Apes: Extractive Industries and Ape Conservation. Cambridge: Cambridge University Press.

Reichard U. 1998. Sleeping sites, sleeping places, and presleep behaviour of gibbons (Hylobates lar). American Journal of Primatology 46:35-62. https://doi.org/10.1002/ (SICI)1098-2345(1998)46:1<35::AID-AJP4>3.0.CO;2W.

Rubert L. 2007. Identifying Habitat Suitability and Potential Linkages for Swamp Rabbit Conservation in Southern Illinois. Southern Illinois: Department of Zoology in the Graduate School, University Carbondale.

Whitten AJ. 1982. The role of ants in selection of night trees by gibbons. Biotropica 14(3):237-238. https://doi.org/ $10.2307 / 2388031$
Rinaldi D. 2003. The study of javan gibbon (Hylobates moloch Audebert) in Gunung Halimun National Park (Distribution, population and behavior). Research and Conservation of Biodiversity in Indonesia 9:30-47.

Rowe N. 1996. The Pictorial Guide to the Living Primates, New York: Pogonias Press.

Setiawan A, Nugroho TS, Wibisono Y, Ikawati V, Sugardjito J. 2012. Population density and distribution of javan gibbon (Hylobates moloch) in Central Java, Indonesia. Biodiversitas 13(1):23-27. https://doi.org/10.13057/ biodiv/d130105.

Setchell JM, Curtis DJ. 2003. Field and Laboratory Methods in Primatology. Cambridge: Cambridge University Press. https://doi.org/10.1017/CBO9781139165105.

Supriatna J. 2006. Conservation programs for the endangered javan gibbon (Hylobates moloch). Primate Conservation 21:155-162. https://doi.org/10.1896/0898-6207.21.1.155.

Supriatna J, Wahyono EH. 2000. Panduan Lapangan Primata Indonesia. Jakarta: Yayasan Obor Indonesia.

Suheri H, Nakagoshi N, Suwandana E. 2014. Habitat suitability and assessment of corridors setup for javan gibbon conservation: A case study in Gunung Gede Pangrango National Park, Indonesia. Asian Journal of Conservation Biology 3(1):19-27.

Tobing ISL. 2002. Respon primata terhadap kehadiran manusia di kawasan Cikaniki, Taman Nasional Gunung Halimun. Berita Biologi 6(1):99-105.

U.S. Fish and Wildlife Service. 1980. Habitat Evaluation Procedure (HEP). Division of Ecological Service. Ecological Service Manual 102. Washington D.C.: Government Printing Office.

U.S. Fish and Wildlife Service. 1981. Standards for the Development of Suitability Index Models. Division of Ecological Services. Ecological Service Manual 103. Washington, D.C.: Government Printing Office.

Wedana M, Iskandar S, Setiawan A, Wibisono Y, Nugroho TS, Prasetyo D, Oktavinalis H, Simanjuntak CN. 2009. Preliminary Study on Updating Javan Gibbon Population and Distribution in West and Centra Java. APAPI. 